\title{
The Role of Financial Institutions from the Aspect of Innovated Banking Products and Services as the Reply of Banks in Serbia to the Changes in the Environment
}

\author{
MILETIĆ Lidija ${ }^{17}$, ILIĆ Milena ${ }^{18}$, KASTRATOVIĆ Edita ${ }^{19}$
}

\begin{abstract}
Numerous changes from the economic and technological environment of financial institutions have led banks into innovating their products and services in order to adequately respond to new needs, i.e. the needs of new consumers, because together with the environment their needs and preferences are changed.

Banks in Serbia according to the legislative framework have the possibility to perform various tasks. In practice, banks operating in Serbia offer certain groups of products and products that are difficult to differentiate. Today, with the aim of responding to the demand of more and more self-conscious consumers, the banks use the Internet or electronic banking as a modern channel for the distribution of banking services.
\end{abstract}

Keywords: financial institutions, banking sector, strategic management, innovations, consumers, services

JEL: F60, G21, M20, O30

UDC: 336.711(497.11)

336.132.1(497.11)

COBISS.SR-ID 265404684

\section{Introduction}

Beside taking care of client satisfaction, achieving the certain level of value of employees and development of their competitions, price policies and other problems, banks are continously reviewing existing and implementing new products.

Banking management recognises the importance of achieving satisfaction with service users and the role employees have in securing this satisfaction, so their goal is to have as much competent human resources as possible. Banks are also striving to ensure that the costs of their operations are as low as possible, because costs are involved in pricing. It is important that costs affect the formation of the selling price of banking products or services, since the bank's goal is to make the product as fast as possible and atthe lowest possible cost, as it affects the efficiency of the total value chain.

\footnotetext{
${ }^{17}$ Hight Vocational School of Information Technology, Belgrade, Serbia

${ }^{18}$ Hight Vocational School of Information Technology, Belgrade, Serbia

${ }^{19}$ Faculty of Business Economics and Entrepreneurship, Belgrade, Serbia
} 


\section{Banking products and services in Serbia}

In accordance with the Banking Law, the Bank is a "joint-stock company with headquarters in the Republic of Serbia, which has a license for the work of the National Bank of Serbia and performs deposit and credit operations, and may perform other tasks in accordance with the law". Pursuant to the aforementioned law, banks in Serbia can perform deposit operations, credit operations, currency operations, foreign exchange and currency exchange operations, payment transactions, issuing payment cards, securities transactions, brokerage and dealer operations, warranty services, purchasing, selling and collection of claims, insurance representation activities, affairs for which they are authorised by law, other affairs whose nature is similar or related to previously listed jobs. The Banking Act defines the tasks that can only be dealt with by banks. Namely, it is about giving loans and issuing payment cards. (Ilić, 2017, p. 160)

The range of banks' services can be divided into retail, small business and corporate business. Business banks of Serbia offer their clients, individuals, different products, or services. The services provided by banks in relation to the population are as follows: current accounts, loans for short-term and long-term borrowings of the bank, maximally adjusted to the needs of the population, at a certain interest rate that represents the cost of the loan, bank risk if the loan is not returned (dinar cash loan in dinars with variable interest rate and with fixed interest rate, refinancing loan, cash loan indexed in EUR, deposit credit, multipurpose consumer loan, legalisation loan, housing loan, euro trade, euro auto, subsidised loan), savings, payment card e-statement, prepaid credit, non-payment, standing order, sms notifications, ebanking and ATMs/aps. (Ilić, Radnović, 2011, pp. 134-143)

Bank's legal entities in Serbia usually offer standard and innovative banking products: account opening, foreign exchange transactions (money market, HOV, foreign exchange, research and advisory services, as well as structural service products related to domestic and foreign payment transactions), documentary operations, deposits and loans.

The most frequent products or services intended for individuals (retail) in the offer of banks in Serbia are: dinar accounts (current dinar accounts and different packages), foreign currency accounts (current foreign currency accounts), payments/inflows(permanent order, foreign currency payments, currency exchange, money transfers from abroad), electronic services (electronic banking, mobile banking, telephone banking, sms banking), loans (dinar cash loans, dinar loans for refinancing, housing loans and consumer loans), cards (credit cards, debit cards, gift cards), savings (term deposits, by sight, step-by-step) and insurance (life, travel, household insurance, voluntary health insurance).

The most frequent products or services intended for corporates, that is, legal persons, in the offer of banks in Serbia are payment operations (current account, domestic payment operations, international payment operations), corporate loans (short-term loans, long-term loans, EIB credit line),domestic factoring operations, international factoring operations, discount bills, escort letters of credit), deposits (overnight deposits, time deposits, sight deposits), payment cards (payment cards, POS terminals, e-commerce) and electronic banking.

Banks in Serbia offer different banking products or services to corporate clients, in comparison to a small-business client. For small-business clients, they most commonly offer: payment operations (packages of products and services for small businesses, current accounts, overdraft on a currentaccount, domestic payment operations, international payment systems), small business loans (working capital loans, investment loans, credit cards and other loans), payment cards (credit cards, debit cards), acceptance of payment cards (POS terminals, ecommerce) and electronic banking.

Regarding the innovation of existing banking products, there are also new channels of distribution of banking products and services, such as internet banking. Internet banking is a relatively new channel for the distribution of banking products and services and 
communications with numerous benefits such as time and space unlimitedness, price, faster interaction, and more. (Primorac, Smoljić, Bogi, 2012, pp. 305-316) As the number of households that own computer and have Internet access grows both in the world and in Serbia, this segment of banking is growing both in the world and in Serbia. More and more people understand and accept the benefits offered by inernet banking-saving time for service execution, no queuing and transactions can be done 24 hours a day/7 day a week. However, sometimes new products that follow global development tendencies cannot, by themselves, be enough for customers. On the other hand, some products also become less attractive. Banks, in order to remind customers of some of their products, offer certain rewards. This does not modify the product, but the promotion attracts attention to it. For example, UniCredit Bank was donating vouchers for the purchase of goods for apartment furnishing in the amount of 25,000 dinars for all the clients who apply for a housing loan until June 30, 2015, or to whom the loan was granted.

Due to the development of new technologies, and in general innovations in other industries and sectors, such as telecommunications and IT, banking has developed its products and services.

\section{Changing banking products and services in response to demand}

Work and capital-based organisations are increasingly being replaced by knowledge-based organisations because their success and survival are conditioned by the creation of newer, better and more innovative products and services. Due to a high degree of competitiveness and globalisation of the modern market, each business segment must be thoroughly planned. (Kastratović et al., 2017, p. 50).

Banks are developing new and innovating existing products to adequately respond to changes that come from the environment. Namely, there are different trends in the society and the economy that shapeboth of them. General trends that have an impact on banking are, among other things, globalisation, deregulation and the development of information technologies. (Zelenbabić 2011, pp. 283-298).

Those banks that were able to adapt their business strategies used the positive sides of globalisation, merged with other banks from the region, other continents, built up new business entities, took over smaller banks, investment companies, insurance companies and the like. In other words, banks have adapted their business strategies to globalisation.

The focus on global business caused the dynamic development of technology, so that technology developed, and especially IT technology. Technology is rapidly evolving and modern, current technological changes are causing the emergence of new trends in the world.

Therefore, in many industries, the size of organisations is reduced, not only those organisations belonging to the "high-tech" industry, or "IT-industry", but also organisations from various industries (Jevtić, Čudanov, Dulanović, 2005, pp. 12-18). Today, there are also changes in banks that are conditioned by the development of technology and process automation, as well as outsourcing processes. Since the social environment is subject to continual changes, this implies that the basic assumptions that were valid yesterday might become invalid tomorrow and can easily go in the wrong direction (Kastratović, E, 2008, p. 23). In such a context it is very important to know how to manage the changes and apply the knowledge in concrete business activities, in this case in banking. Due to increasing competition in the services, it is necessary to define the way the post offices and banks can act in the market.

In recent business environment, each bank and post office in Serbia aims to achieve a new competitive service, both in price and quality. The financial services include: payments, money transfers, bank services, remittances, e-services, cash express services, ATMs, free shares, 
services for the PostanskaStedionica bank, as well as exchange office. There are also additional services such as logistic ones, including: IT services, philately, product sale and other services realised in cooperation with other organisations (Ratković, Pavlović, Anđelković, 2017, p. 109). The development of information and communication technologies has a major impact on the performance of the company, primarily on the productivity of the company through various internal and external factors (Jevtic, Jasko, Chudanov, 2007, pp. 12-18).

Table 1 shows the effects of new management structures and informational technologies on productivity (Brynjolfsson, Hill, 1998, p. 8).

Table 1. Effects of new management structures and informational technologies on productivity

\begin{tabular}{|l|l|l|}
\hline & $\begin{array}{l}\text { Smaller investments in } \\
\text { IT }\end{array}$ & Biggerinvestments inIT \\
\hline $\begin{array}{l}\text { Significant restructuring of the } \\
\text { management }\end{array}$ & $\begin{array}{l}\text { Smaller productivity } \\
\text { growth }\end{array}$ & $\begin{array}{l}\text { Bigger productivity } \\
\text { growth }\end{array}$ \\
\hline $\begin{array}{l}\text { Insignificant restructuring of } \\
\text { management }\end{array}$ & $\begin{array}{l}\text { No effect on } \\
\text { productivity }\end{array}$ & Productivity decline \\
\hline
\end{tabular}

Resource: Brynjolfsson, E. and L. Hitt, "Paradox Lost? Firm-level Evidence on the Returns to Information Systems Spending”, Management Science, April, (1996). (Reprinted in Willcocks, L. and Lester, S. (eds.). Beyond the IT Productivity Paradox: Assessment Issues. McGraw Hill, Maidenhead. (1998), p. 8

Thanks to the development of technics and technology (primarily the development of information technologies), electronic banking is developing. Of course, in order to develop electronic banking, it was necessary to develop payment transactions.

For a long time, governments and theorists of the banking sector have argued about one dilemma: whether the banking sector needs regulation or deregulation.

Nevertheless, deregulation is one of the trends that, in addition to the globalisation and information technologies development, is causing changes in the banking sector.

Banks must decide as to when to launch a new banking product or service.

Also, a banking product must be launched in a particular market, or for a defined market segment, and the management of the bank must decide about the market or segment in question. Also, the management of the bank must decide which potential consumers a product will be placed to, as well as which marketing strategy will be selected for the introduction of the new product on the market.

Filipović and Kostić-Stankovićdivideproducts according to the criterion of marketing into industrial goods, consumables and services. (Filipovic, Kostic-Stankovic, 2012, p. 180) According to this division, industrial goods are those usedby enterprises for further production.

Also, according to these authors, consumer goods are divided into disposable goods and durable consumer goods.

Disposable products according to these authors are food, products of personal hygiene, cosmetics and others. Durable goods are household appliances, clothes, furniture. Services are products that are offered to customers and which are not materialised. Services are difficult to separate from the product they are to some extent connected with.

Kotler believes that the service is "an activity or benefit that one party offers to another and which is essentially intangible and does not result in ownership over anything. Its production can, but not necessarily, be associated with physically tangible good." (Kotler 2012, p. 430)

When it comes to banking, there is an indivisibility of the process of production and use of services, as well as in other service activities, which is why it is important to understand the 
significance of a service user due to his or her presence during the service manufacturing process itself. In this process, employees, or those who produce the service, also play an important role.

Eurobank Srbija has promoted the service of a personal banker, emphasising the importance of employees and the importance of clients or consumers, where consumers will, as they are important for the bank, have their own "personal" banker with whom they will talk about the services or products of the bank. "A personal banker is your exclusive partner," says the slogan. An important leitmotif is the sentence "Your relationship with the bank becomes personal."

The most common products or services offered by banks in Serbia can be divided into products or services intended for individuals and products, i.e. services intended for corporate clients or legal entities.

\section{Innovating banking products in Serbia}

Banks are in a turbulent environment. The competition is high. Therefore, banks need to innovate their products and services. Perhaps this is not innovation in the true sense of the word. Namely, the etymological origin of the word "innovation" is from the Latin word "innovare" which means to create, to make something new. (Stošić, 2007, p. 17) One very good definition of innovation says: "Innovation means the renewal and expansion of the range of products, services and their markets, the establishment of new ways of production, procurement and distribution, the introduction of changes in the way of management, the organisation of work, work conditions and skills of the workforce". (Stošić, 2007, p.19)

Banks often do not dare to innovate their products in the true sense (etymological sense) of the meaning of the word of innovation, but rather try to go in a tried and tested way and rely on innovations from other industries, or from other sectors. Banks are therefore trying to make their existing products and services change or supplement them, i.e. rationally manage their products, in accordance with marketing postulates.

Banks need to test markets for their products in order to reach the following knowledge (Salai, 2001, p. 93):

- Whether the target market will accept the product as it was created in the development phase, without seeking change,

- If the clients of the bank want to make changes to the product, what exactly they expect and if they accept the altered product,

- whether to launch or not to launch the product, if consumers are not ready to accept it.

The strategy of innovating the assortment of banking products follows the general trend in banking that in fact implies diversification of the range of banking products that the bank offers to its customers. In addition, there is the modification of existing products or extensions of existing lines.

The development of new products in banks goes through certain phases. The first stage is the collection of different ideas for the development of new products.

At this stage, with the help of various well-known techniques from employees in the services, that is, marketing and/or external associates, various ideas for product development are gathered. When enough ideas are gathered, the process moves to the next phase. The next phase is the analysis of the collected ideas, in order to make a choice of the most optimal idea.

After this phase, the idea selected is going through a critical judgment, or a feasibility study is carried out, to determine whether the selected product development idea is good enough, or whether it will yield enough good results and therefore achieve the bank's goal of growth and profit. If a feasibility study has convinced management that the idea of product development 
has been chosen as a good solution for a specific bank, it is approaching the development of a new product. After product development, its testing is carried out. This phase is extremely important. If it goes well, the final stage is commercialisation. Commercialisation represents the introduction of the product toa market, and it must be accompanied by adequate marketing, i.e. promotion and advertising in the first place. In our market it has happened that banks offered a new product, or service with some gifts.

In the last decade of this century, the basis for the diversification of the product range of banking products is the development of information technologies.

Namely, due to the development of information technologies, banks have developed an electronic money transfer in order to save their work and documentation, in order to make customers pay in real time. In the area of self-service banking, banks have developed certain electronic systems for performing payment operations. It is about bank machines, computers at the point of sale and home banking (Lukić, 2013, p. 66). The products in the area of retail and supply to individuals have been innovated, due to innovations and monitoring of the development of information technologies and their use in the banking sector.

Bank automation machines are placed at the points of sale and allow customers to withdraw money from their account during and after working hours, check the balance on them, pay money, transfer money, etc.

Computers at points of sale allowshop assistants to check the goods in stock, the state of the consumer's account at the bank, consumers using debit and credit cards to pay for the goods they bought, etc.

Home banking enables clients to transfer their money from their bank accountsto the accounts of goods or services sellers, as well as other servicesfrom their home.

Banks in the world have innovated their product range and, among other things, introduced cash management products. Cash management means managing cash flows of clients who are legal entities. More precisely, it is a bank product that relates to the management of all client accounts in the bank. (Barjaktarović, Marković 2014, pp. 48-69.)

Domestic banks that are based on foreign capital were among the first to introduce modern cash management products. Banks that are developing cooperation with corporate clients and for whom it is a corporate advantage are constantly developing cash management products in Serbia. These are Banca Intesa, Raiffeisen Bank, Erste Bank and UniCredit Bank. The results of the research within the Project of the Ministry of Science of the Republic of Serbia, no. 47028: Improving Serbia's competitiveness in the process of EU accession in 2009 and 2012, indicate that domestic banks founded with Italian capital, such as Banca Intesa and UniCredit Bank, are leaders in the introduction of new modern Cash Management products. (Barjaktarović, 2014, pp. 48-69.)

Thanking to the innovating of banking products, loans for debt refinancing as an extension of product lines have been created. Today all the banks in Serbia offer loans for refinancing credit products with these banks, or with some other banks. Each of them promotes its loans as the best in the market. Some banks, along with refinancing loans, also offer certain gifts, such as money, tablets, etc.

Also, in the offer of Serbian banks, financial leasing has emergedas a new product in the last decade, as a good way to obtain or renew permanent funds.

Banks even established subordinate units that would deal only with leasing, such as Raiffeisen Leasing, ProCredit Leasing and more.

In addition to the products listed, other banking products or services appeared over time, which were innovative, of course, for a certain period of time. Then, these innovations would become obsolete, and the banks would seek new innovations, or new inventions before all, followed by new innovations. It is necessary to look for them in new technologies and new 
processes, then on the basis of them innovate the products, but not just their products. Much can be innovated in one business organisation, and therefore in banks.

What is important to note is that in banking today, the life cycle of products decreases, that is, the time interval in which a product can be considered new, and the innovations quickly become obsolete. Therefore, in addition to the fact that banks have to pay great attention to products or services as an element of marketing mix, because banks today are marketingoriented and understand the value and importance of their clients, they must pay attention to other elements of marketing mix.

So, the product/service is important, but the prices are also important, as well as distribution channels and promotion. In addition, marketing mix elements that are characteristic of service marketing are also important for the bank. These are: service ambience, people and the service process. (Veljković S, 2009 p.68)

Table 2 shows additional, i.e. additional marketing mix instruments that are characteristic for the service sector.

Table 2. Additional elements of service marketing mix

\begin{tabular}{|c|c|c|}
\hline $\begin{array}{l}\text { Service } \\
\text { environment }\end{array}$ & People & Service process \\
\hline $\begin{array}{l}\text { Design of the object } \\
\text { (exterior and interior) } \\
\text { Equipment } \\
\text { Signs and symbols } \\
\text { Employees' clothes } \\
\text { Other tangible } \\
\text { elements }\end{array}$ & $\begin{array}{l}\text { Employees } \\
\text { (recruiting, training, motivation, } \\
\text { prices, team work) } \\
\text { Consumers, users } \\
\text { Services (behaviour, degree of } \\
\text { engagement, contact between } \\
\text { consumers, education, training) }\end{array}$ & $\begin{array}{l}\text { Activity flow (standardised, } \\
\text { tailored to individual } \\
\text { requirements) } \\
\text { Number of steps in service } \\
\text { delivery } \\
\text { simple, complex process) } \\
\text { Consumer involvement and } \\
\text { targeting }\end{array}$ \\
\hline
\end{tabular}

Source: Veljković, 2009, p. 68.

\section{Conclusions}

What all theorists agree on is that innovations enable improvement of the quality of products and services, increase security and lead to increased competitiveness. Banks, due to the great competition and rapid development of telecommunication technologies and IT sectors, have to constantly innovate their products and services. Once transferred to a banking product or service, it can quickly become outdated and, for these reasons, the bank must constantly and continuously innovate in its business.

Analysts say there are no innovations in banking in the true sense of the word, but banks use genuine innovations from other sectors, and use them to diversify or modify their own products or services. Based on the conducted research, it can be concluded that banks in Serbia are doing this relatively well.

\section{REFERENCES}

1. Barjaktarović, L., Marković, M. (2014). Cash managment koncept, Bankarstvo, vol. 43, no. 5, pp. 48-69.

2. Brynjolfsson, E., L. Hitt. (1996). Paradox Lost? Firm-level Evidence on the Returns to Information Systems Spending, Management Science. (Reprinted in Willcocks, L. and Lester, S. (eds.). Beyond the IT Productivity Paradox: Assessment Issues. McGraw Hill, Maidenhead. (1998)) 
3. Chandler, A. (1962). Strategy and structure: chapters in the history of the industrial enterprise, The MIT press, p. 2 dostupna na: https://archive.org/details/strategystructur00chan_0 (datum pristupa 27.01.2017. godine)

4. Filipović, V, Kostić-Stanković, M. (2012). Marketing menadžment, Fakultet organizacionih nauka, Beograd.

5. Ilić, M. (2017). Osnove ekonomije, finansija i računovodstva, Visoka škola strukovnih studija za informacione tehnologije, Beograd.

6. Ilić, M., Radnović, B. (2011) "Upravljanje uslugom kao instrumentom marketing miksa - primer Euro Bank EFG Beograd” Bankarstvo, vol. 40, no. 11-12, pp. 134143. UDK 336.71 (497.11).

7. Jevtić, M., Čudanov, M., Dulanović, Ž.I. (2005). Uticaj informacionokomunikacione tehnologije na veličinu preduzeća, Management: Journal for Theory and Practice Management, vol. 10, no. 40, pp. 12-18.

8. Kastratović, E. (2008). Uvod u menadžment, Beograd: Fakultet za menadžment u sportu Univerziteta "Braća Karić", 225 str., ilustr. ISBN 978-86-86197-24-5. [COBISS.SR-ID 154583564].

9. Kastratović E., Kaličanin M, Kaličanin Z. (2017). Features of Cash Flow Compared to Profit, International Review, No. 3-4, pp. 50-57.

http://www.vspep.edu.rs/_img/downsekcija/2018/02/ejournal_international_review_ no_3_4_2017.pdf

10. Kotler, P. (2012). Marketing Management, $9^{\text {th }}$ Edition, Prentice-Hall.

11. Lukić, R. (2013). Bankarsko računovodstvo, CID Ekonomskog fakulteta u Beogradu, Beograd.

12. Primorac, D., Smoljić, M. Bogi, N. (2012). Moguće strategije banke u poboljšanju usluga internet bankarstva - analiza obeležja korisnika, Megatrend revija, vol. 9, no. 3, pp. 305-316.

13. Ratković M., Pavlović M., AnđelkovićM. (2017). Comparative Analysis of Customer Satisfaction in Postal and Banking Services, International Review, No.1-2. pp. 108121. internationalreviewno.pdf

14. Salai, S. (2001). Marketing istraživanje, Savremena Administracija, Beograd.

15. Stošić, B. (2006). Menadžment inovacija, ekspertni sistem, modeli i metode, Fakultet organizacionih nauka, Beograd.

16. Veljković, S. (2009). Marketing usluga, Centar za izdavačku delatnost ekonomskog fakulteta u Beogradu, Beograd.

17. Zakon o bankama ("Sl. glasnik RS", br. 107/2005, 91/2010 i 14/2015).

18. Zelenbabić, S. (2011). Procesi globalizacije i njihov uticaj na sektor bankrstva u zemljama Jugoistečne Evrope sa posebnim osvrtom na Bosnu i Hercegovinu, Druga međunarodna naučna konferencija "Ekonomija integracija", pp. 283-298 Ekonomski fakultet, Tuzla.

\section{Article history:}

Received 15 April 2018

Accepted 10 June 2018 